\title{
Relationship between soil organic matter fractions and cover plants in Olive post planting
}

\author{
Danielle Vieira Guimarães ${ }^{1}$, Marx Leandro Naves Silva ${ }^{2}$, Adnane Beiniach ${ }^{1}$, \\ Diêgo Faustolo Alves Bispos ${ }^{3}$, Jéssica Gabriela Pimentel Contins ${ }^{4}$, Nilton Curi². \\ Abstract- Erosion is the main cause of soil degradation, compromising soil productivity and \\ sustainability. As soil organic matter (SOM) is a key indicator of quality, this study aimed to \\ evaluate the effect of different olive tree managements on SOM and its soil fractions in soil \\ (Inceptisol) and erosion sediments. Five treatments were installed: bare soil, olive cultivation in \\ bare soil, olive tree intercropped with jack bean, olive tree intercropped with pearl millet, and olive \\ tree cultivated with spontaneous vegetation; a contiguous area of native vegetation was used as \\ reference. Carbon in soil and sediment were determined by wet oxidation with external heating, \\ while the fractionation of SOM was performed based on granulometry. The Carbon Management \\ Index (CMI) was determined by the proportions of SOM fractions. The results indicated that SOM \\ associated with minerals is the most present in soil and sediment erosion, regardless of the adopted \\ management. Results on CMI showed that the systems olive tree intercropped with pearl millet \\ or with spontaneous vegetation are the most favorable to increase the carbon stock in the soil. \\ Index terms: Carbon Management Index; cover plants; Olea europaea L.

\section{Relação entre frações da matéria orgânica do solo e plantas de cobertura em pós-plantio de Oliveira}

Corresponding author: danyvguimaraes@hotmail.com

Received: March 19, 2018. Accepted: September 17, 2018.

Copyright: All the contents of this journal, except where otherwise noted, is licensed under a Creative Commons Attribution License.
Resumo- A erosão é a principal causa de degradação do solo, comprometendo a produtividade e a sustentabilidade do solo. A matéria orgânica do solo (MOS) é um indicador chave da qualidade; deste modo, o presente estudo objetivou avaliar o efeito de diferentes manejos da oliveira na matéria orgânica e em suas frações presentes no solo (Cambissolo) e no sedimento de erosão, no sul de Minas Gerais. Foram instaladas parcelas com 5 tratamentos: solo descoberto, cultura de oliveira em solo descoberto, oliveira em consórcio com feijão-de-porco, oliveira em consórcio com milheto e oliveira com vegetação espontânea, além de uma área contígua de vegetação nativa como referência. $\mathrm{O}$ carbono do solo e do sedimento foi determinado via oxidação úmida com aquecimento externo, enquanto o fracionamento da MOS e do sedimento foi realizado com base na granulometria. O Índice de Manejo de Carbono (IMC) foi determinado por meio das proporções das frações da MOS. Os resultados indicaram que a MOS associada aos minerais é a mais presente no solo e no sedimento de erosão, independentemente do manejo adotado. O IMC apontou os sistemas oliveira com milheto e oliveira sob vegetação espontânea como os mais favoráveis ao estoque de carbono no solo.

Termos para indexação: Índice de Manejo de Carbono; plantas de cobertura; Olea europaea L. 


\section{Introduction}

The olive tree (Olea europaea L.) is a wellknown evergreen tree, native to the Mediterranean region, brought to Brazil by European immigrants in the period of Brazil colony. However, production in the country is still insignificant (WREGE et al., 2015). Olive oil is highly valued in the Brazilian market, with approximately 240 million dollars spent on its importation in 2015 (IMETRO, 2015) to meet national demand. This suggests the need for scientific research and technological adaptation to increase national production (OLIVEIRA et al., 2006) due to the lack of information on implantation and sustainable management, especially with respect to soil conditions (FERREIRA et al., 2015).

The young olive tree plant presents a small leaf area and, considering the adult phase, the physiological need of great spacing between plants offers little protection to the soil. On the other hand, the presence of cover plants or associated leguminous plants can compromise the development of the olive (MARTINS et al., 2015), which has contributed to the use of management systems where the soil between the lines of the crop is exposed to erosive processes, compromising soil quality (SQ).

In olive cultivation, soil loss is higher than soil formation rate, mainly due to water erosion, resulting in a reduction in the water storage capacity of the system, reduction of the amount of available nutrients and loss of the root system of the tree. In addition, there are risks associated with pollution by pesticides transported via surface runoff and associated with soil particles (IOOC, 2007).

A survey of olive tree erosion conducted by Sastre et al. (2016) found that these were predominant in Spain, followed by Italy and Greece, with a lack of studies conducted in Brazil and the tropics. The authors also affirmed that after one year of olive tree cultivation, the establishment of the canopy is sufficient to reduce sediment formation to a tolerable level, indicating the first year of the crop as the most critical for erosion occurrence, and thus, requiring greater monitoring of the erosive process.

The slope of the area and the low density of olive trees are pointed out by Fernandez-Romero et al. (2016) as the main responsible factors for the high rates of erosion in olive groves, resulting in soil degradation and raised recovery costs. In addition, the authors warned about the need to determine SQ indices for olive tree management systems, aiming to identify alternatives to sustainable systems with emphasis on soil organic matter (SOM).

SOM is highly dynamic and sensitive to management and thus considered a key indicator of SQ. In general, SOM is associated with soil productivity due to increases of cation exchange capacity, soil aggregation, and water retention (ARTEMYEVA e KOGUT, 2016; BARBOSA et al., 2016; ZHAO et al., 2015). Although the amount of SOM has been usually estimated from the soil organic carbon (SOC), the total soil content is not very sensitive to changes of land use and management in short-term (LEITE et al., 2003). On the other hand, the granulometric fractionation of SOM, which separates it into labile and non-labile fractions, has proved to be an efficient alternative in the evaluation of the effects of management systems, with greater sensitivity of the fractions in a short-term, boosting the use of SOM as an indicator of SQ (GUIMARÃES et al., 2013; SHENG et al., 2015).

The labile fraction of SOM participates directly in the trophic soil network and, therefore, influences nutrient recycling and related biological properties. It can be determined based on particle size and degree of association with soil mineral fractions as a measure of its bioavailability (OLIVEIRA et al., 2016). Research evaluating the sensitivity of 17 SQ indicators identified the carbon of the labile fraction as one of the most efficient forms (SOUZA et al., 2014). For Silva et al. (2016) the importance of studying this fraction is highlighted when the time of evaluation is insufficient to detect changes caused in SOC contents by the managements. The labile fraction has a high recycling rate of organic compounds and is a source of energy for soil microorganisms.

Based on the granulometric fractionation of SOM, it is possible to obtain indices that aid in the evaluation of soil quality. For example, the Carbon Management Index (CMI), which reflects the lability and stock of carbon in soil, being widely used as a sensitive indicator of total organic carbon (TOC) rate changes in response to changes in soil management (ZHAO et al., 2014). Kunde et al. (2016), when comparing treatments in cane fields with one, three, and five years of implantation, observed that time did not cause significant differences for CMI and the Lability Index (IL) obtained from SOM fractions, which are efficient in the evaluation of cultivation systems even for one year of implementation.

Anthropogenic water erosion reflects of incorrect land use and management, which can degrade soil structure, reduce infiltration, and increase surface runoff, resulting in high economic impacts (LAL, 2015). In this sense, SOM fractions and their indices can be used as predictive tools on the impacts of water erosion and soil quality. Thus, the lack of studies that relate these indices and SOM fractions to the impacts generated by water erosion in olive plantations under tropical conditions justify this study.

This study aimed to evaluate the effect of different olive tree management system on organic matter and its soil fractions in soil (Inceptisol) and erosion sediment in the South of Minas Gerais, considering the post-planting period. 


\section{Materials and methods}

Description of the experimental area - The experiment was carried out in Lavras, southern Minas Gerais state, Brazil (Figure 1). The climate is Cwb, characterized as humic subtropical with dry winter and temperate summer, with average rainfall and annual temperature of $1.411 \mathrm{~mm}$ and $19.3{ }^{\circ} \mathrm{C}$, respectively (ALVAREZ et al., 2013). The soil was classified as Inceptisol according SANTOS et al. (2013) and the average slope of the area is $23 \%$.

Prior to the installation of the experiment, soil characterization was carried out in three portions of the relief (Table 1 and Figures 1 and 2), using composite samples. The area was previously occupied by Brachiaria decumbens, being scoured every three months. The physical and chemical analyzes were performed according to Silva et al. (2009).

Installation of standard plots erosion and sampling of soil and sediment - Standard plots of water erosion monitoring were installed to quantify the amount of soil losses and their constituents. The plots, with three replications each, were $12 \times 4 \mathrm{~m}$ installed in the direction of slope $(23 \%)$, with the following treatments: bare soil (BS), olive tree cultivated on bare soil (OBS), olive tree intercropped with jack bean (Canavalia ensiformis) (OJB), olive tree intercropped with Pearl millet (Pennisetum glaucum) (OML), and olive tree cultivated with spontaneous vegetation (OSV). The dry matter of the cover crops after their first cycle is shown in Table 2. For SOM studies, an area of native vegetation (NV) was adopted as reference in the same conditions of climate, soil and landscape position of the area experimental, located $500 \mathrm{~m}$ next to the plots.

Olive tree planting was carried out in March 2015 , after the soil of the $0-20 \mathrm{~cm}$ layer was plowed, and cover crops of jack beans and millet were installed by manual seeding. Olive seedlings were planted in pits of $50 \mathrm{dm}^{3}$, spaced by 3 meters, where $500 \mathrm{~g}$ of Single Superphosphate, $200 \mathrm{~g}$ of $\mathrm{KCl}, 10 \mathrm{~L}$ of tanned manure and $100 \mathrm{~g}$ of limestone were added to each well. Planting and fertilization after the first year was performed according to Vieira Neto et al. (2008). Planting of jack beans and millet followed the densities of 8 and 90 seeds $\mathrm{m}^{-1}$, respectively, respecting the direction of the slope and ensuring the coverage of the soil throughout the area. The bare soil plots were thus maintained by means of weeding and the maintenance fertilization in the plots consisted of the addition of $50 \mathrm{~g}$ of ammonium sulphate in November and December 2015 and January 2016.

In the treatment with spontaneous vegetation Brachiaria decumbens is present along with the following species: Ipomoea acuminata, Bidens pilosa, Oxalis corniculata, Digitaria sanguinalis, Emilia fosbergii
Nicolson, Melinis minutiflora, Conyza bonariensis, Euphorbia heterophylla and Eleusine indica.

Sediment sampling was carried out in the $500 \mathrm{~L}$ collection box installed at the end of each plot, delimited by galvanized sheets, which leads the water from the runoff to that box (Figure 3). The material collected after the erosive events considered rainy followed to the laboratory, where the sediment was decanted, oven dried and stored for further analysis. The period of sediment sampling was from September 2015 to September 2016.

For the study of SOM in the plots, sampling was carried out in July 2016, after the rainy season. In each plot, three sites were sampled, considering the upper, middle, and lower portion of the plot next to the planting hole, in the depths of $0-5,5-10,10-20$ and $20-40 \mathrm{~cm}$. In the native vegetation area, nine sites were sampled at the same depths, totaling 216 samples.

Monthly precipitation (Figure 4) was obtained from the INMET (Meteorology Institute) climatological station, which is located approximately $1 \mathrm{~km}$ from the experimental area. Rainfall erosivity was estimated using equation 1, proposed by Aquino et al. (2014) for Lavras.

$\mathrm{EI}_{30}=85.671 \times \mathrm{Rc}^{0,6557}$

Equation 1

where $\mathrm{Rc}=\mathrm{p}^{2} \times \mathrm{P}^{-1}$, in which $\mathrm{Rc}$ is the rainfall coefficient $(\mathrm{mm}), \mathrm{p}$ is the average monthly rainfall $(\mathrm{mm})$ and $\mathrm{P}$ is the average annual rainfall $(\mathrm{mm})$.

Determination and fractionation of SOMThe physical fractions of SOM of the plots and the sediment were separated according to the methodology proposed by Cambardella and Elliot (1992), where soil dispersion was carried out by sodium hydroxide $(0.1 \mathrm{~mol}$ $\left.\mathrm{L}^{-1}\right)$ and 16 hours of agitation using a vertical stirrer. The material was washed in a $53-\mu \mathrm{m}$ sieve and oven dried at 60 ${ }^{\circ} \mathrm{C}$. The particulate organic matter (POM) was determined in this material retained in the sieve and the complexed organic matter (COM) was quantified by the difference between POM and total organic carbon.

After drying, the material retained in the sieve was ground and weighed. The carbon of the soil particulate organic matter (POM-C) fraction was quantified by the wet oxidation method with external heating, proposed by Yeomans and Bremner (1988), and the same method was used to determine TOC. For the conversion of organic carbon to organic matter, a factor of 1.724 was used, based on the assumption that $58 \%$ of SOM is organic C.

For the calculation of the Carbon Management Index (CMI), the carbon pool index (CPI) was considered, according to Equation 2:

$$
\mathrm{CPI}=\frac{\mathrm{TOCc}}{\mathrm{TOCr}}
$$

Equation 2 
where TOCc is the TOC of the cultivated area and TOCr is the TOC of the reference area (native vegetation). Additionally, the Carbon Lability (L) (Equation 3) was calculated:

$$
\mathrm{L}=\frac{\mathrm{Cl}}{\mathrm{CNL}}
$$

Equation 3

Where CL is the carbon of the labile fraction (C-POM) and CNL corresponds to the carbon of the non-labile fraction (C-POM) for each treatment. From the values of lability, the Index of Lability (IL) can be obtained according to Equation 4:

$$
\mathrm{IL}=\frac{\mathrm{L}_{\mathrm{c}}}{\mathrm{L}_{\mathrm{r}}}
$$

Equation 4

where Lc is the lability of the cultivated area and Lr is the lability of the reference area. CMI can be obtained from Equation 5 (Blair et al., 1995):

$$
\mathrm{CMI}=\mathrm{CPI} \mathrm{IL}^{*} 100
$$

Equation 5

Total soil nitrogen, determined at the same depths and sites sampled in for the SOM study, was quantified by sulfur digestion, followed by Kjeldahl distillation.

Statistical analyzes -The data were submitted to analysis of variance in order to identify the effects of the treatments at each soil depth and the means were compared by the Scott-Knott test $(\mathrm{p}<0.05)$. Analyzes were performed using the SISVAR v.5.0 software. The data of carbon fractionations from the sediment were not submitted to statistical analysis due to the low degree of freedom of the treatments.

\section{Results and discussion}

There was no statistical difference for TOC between the treatments (Table 3 ) in any of the evaluated depths, except for the first $5 \mathrm{~cm}$ of soil, in which the average value of the native vegetation was superior. The high contribution of SOM in this case, together with the greater protection provided by the dense vegetation cover to the soil against the effects of the erosion and the absence of plowing in the area, makes this system more conservative in carbon, as expected.

A similar result was observed by Luciano et al. (2010) when evaluating TOC in Inceptisol under tobacco, onion and native forest. The authors found significantly higher values in the native forest only in soil layers up to $10 \mathrm{~cm}$ depth. The deposition of plant residues on the soil surface under forest resulted in a greater contribution of organic matter and, consequently, in the accumulation of TOC in the superficial layer of the soil.
Even in the bare soil treatment, TOC did not decrease in relation to the other management systems. However, in the pre-treatment sampling, it was observed that in the relief portion where one of the parcels with uncovered soil was installed, the TOM content was $38 \%$ higher than that of the medium portion and $50 \%$ higher in relation to the upper proportion (Figures 1 and 2), showing that this area already had higher TOM values before the implantation of the experiment.

The superficial layers $(0-5$ and $5-10 \mathrm{~cm})$ showed decreasing TOC accumulation with depth (Table 3 ). This behavior corroborates the study developed by Loss et al. (2015), which, according to these authors, is favored by the absence of plowing and thus, contributing to the maintenance of a good amount of vegetal residues in the soil surface, besides the root growth of the cover plants, resulting in improvement and maintenance of the soil aggregation of the ground. These results indicate the importance of not revolving the soil and maintaining vegetal cover between the lines of the olive tree.

C-POM showed similar behavior to TOC, with no significant effect of treatments on the fraction of the most labile organic matter. This result was opposite to that commonly observed in the literature, since this fraction is considered very sensitive to the management, being related to the increases in the soil of compounds of easy decomposition that are present in the residues of the cultures (SOUZA et al., 2016). The evaluation period helps to explain the lack of C-POM sensitivity in the management distinction.

The fraction of carbon associated with minerals (C-COM) was more efficient to discriminate the surface layers of the studied treatments, which followed the order $\mathrm{NV}>\mathrm{BS}=\mathrm{OML}>\mathrm{OBS}=\mathrm{OSV}=\mathrm{OJB}$. It is important to emphasize that the uncovered portion presented carbon content before the implantation of the experiment superior to the others, which influenced the result (Figure 2). On the other hand, this C-COM in the soil of the uncovered plot is composed of slightly reactive carbon in the soil and since there is no vegetation cover, there will be no increment of SOM, compromising the biological activity and, consequently, not increasing the soil resistance to water erosion.

$\mathrm{C}-\mathrm{COM}$ tends to be less sensitive to management, since this carbon fraction is physical-protected and more stable. It is also associated to the mineralogy of the finer fractions of the soil, which are not easily affected by the management systems (FACCIN et al., 2016). However, according to Doetter et al. (2015), factors such as climate and erosion can alter soil carbon stabilization in the soil. This can be observed in Figure 5, which shows that the C-COM fraction was the most affected by erosion, with the carbon fraction being more present in the erosion sediment, regardless of the vegetation cover. Kunde et al. (2016) observed a similar result regarding the sensitivity 
of C-COM to the management, attributing the temporal proximity to the soil preparation and stimulating losses of $\mathrm{C}$, since there is a short period for the reestabilization of the organic matter in this fraction.

$\mathrm{C}-\mathrm{COM}$ is associated to the finer mineral fraction, which, according to Martins Filho et al. (2009), tends to be present in a larger quantity in the erosion sediment. The selectivity of the material transported by erosion, which is constituted mostly by finer particles, corresponds to the more reactive fractions of the soil, and, therefore, the ability to remove SOM. However, the results presented in Table 4 show that more than half of the eroded material corresponds to the clay and silt fraction, also emphasizing the concentration of carbon in the complexed fraction of the sediment, which compromises the maintenance of carbon stock in the soil, if conservation measures are not adopted.

Soil lability, which expresses the relationship between C-POM and C-COM, presented values lower than 1 (Table 3), indicating the predominance of carbon in the fraction associated with minerals, which is desirable, since this fraction is more stable. According to Santos et al. (2017), when C-POM predominates, the system becomes more susceptible to $\mathrm{C}$ loss by the action of microbiota, since in this fraction, carbon has low stability and is subject to the highest rate of decomposition. The authors also affirmed that higher amounts of C-COM indicate a predominance of carbon associated to the silt and clay fractions, which, especially in clay, although in small quantities, favors the interaction between the mineral and organic fraction, resulting in the formation of complexes high stability.

Additionally, the C:N ratio of the soil (Table 3) presented low values for all treatments, indicating greater mineralization and faster decomposition, contributing to the predominance of C-COM fraction and lower lability. Fernandez-Romero et al. (2016) also observed low C:N ratio in olive groves, which was attributed to high TOC values. In this study, a decrease in $\mathrm{C}: \mathrm{N}$ ratio in depth was observed, which accompanied the decrease in TOC in the profile due to the higher amount of SOM on the surface and slow carbon movement along the profile, as shown in Table 3. The same tendency was also observed in the vertical distribution of lability due to the increment of material at the initial stage of decomposition at the soil surface.

According to the results presented in Figure 6, no treatment presented CPI (carbon pool index) higher or equal to the reference area; the lowest CPI was observed in OBS and the greater value in OML and BS. In the latter case, the highest initial value of SOM in this area, compared to the others, was maintained constant in a situation where the contribution of SOM is small, showing no abrupt reduction in soil carbon content in the first year after the removal of the vegetal cover and, thus, this reduction tends to be slow and gradual.
All the evaluated systems showed higher lability index than the reference (Figure 6). The lowest value was observed in the soil without vegetation cover, which reflects the absence of vegetation and consequently the null input of SOM. In this sense, this index can aid in the identification of systems that pose risks to the maintenance of soil carbon stock.

Moreover, the carbon and its fractions present in the eroded sediment from the area without vegetation cover was superior to the others (Figure 7), indicating that regardless of the amount of soil lost due to erosion, carbon removal where there is no contribution of SOM is high when compared to systems with plant cover. The CMI (Figure 8) shows the influence of land use on TOC, where values above or below 100 indicate positive or negative impacts on soil quality, respectively (GUIMARÃES et al., 2014). For this index, only OSV and OML presented higher values than the reference area and, therefore, are the ones that contribute the best quality to the soil. Although jack beans presented higher biomass compared to millet (Table 2), the decomposition of legume in the soil tends to be more accelerated, especially in the tropic conditions that this study was performed. According to Conceição et al. (2014), the high input of biomass results in an increase in the CMI, reflecting the effect of conservation systems on increasing the quantity and the lability of organic matter in the soil. 
Table 1. Soil physical and chemical attributes prior to experiment setup.

\begin{tabular}{ccccccccccccc}
\hline Depth & pH & K & P & Ca & Mg & Al & H+Al & P-Rem & MOT & Clay & Silt & Sand \\
\hline $\mathrm{cm}$ & \multicolumn{4}{c}{${\mathrm{mg} / \mathrm{dm}^{3}}^{2}$} & $-------\mathrm{cmolc}^{2} \mathrm{dm}^{3}-------$ & $\mathrm{mg} / \mathrm{L}$ & $------------\%$----------- \\
$0-10$ & 5.33 & 109.00 & 9.37 & 2.47 & 0.66 & 0.13 & 2.31 & 26.49 & 2.23 & 40 & 19 & 41 \\
$10-20$ & 5.37 & 64.22 & 2.83 & 1.84 & 0.49 & 0.16 & 2.23 & 23.92 & 1.44 & 40 & 20 & 40 \\
$20-40$ & 5.26 & 47.67 & 1.46 & 1.54 & 0.42 & 0.19 & 2.10 & 19.02 & 1.09 & 42 & 20 & 38 \\
$40-60$ & 5.42 & 30.67 & 0.92 & 1.44 & 0.36 & 0.15 & 1.93 & 14.45 & 0.65 & 45 & 23 & 32 \\
\hline
\end{tabular}

Table 2. Dry weight of the cover crops in the plots.

\begin{tabular}{ccc}
\hline & Millet & Jack beans \\
\hline Plot & \multicolumn{2}{c}{ Dry weight $\left(\mathrm{t} \mathrm{ha}^{-1}\right)$} \\
\hline 1 & 9.35 & 17.48 \\
2 & 12.14 & 16.23 \\
3 & 12.23 & 26.42 \\
\hline
\end{tabular}

Table 3. Total Organic Carbon and its fractions in management systems of cover crops in olive cultivation in the southern region of Minas Gerais.

\begin{tabular}{|c|c|c|c|c|c|c|}
\hline Depth & OBS & OSV & OJB & OML & $\mathrm{BS}$ & $\mathrm{NV}$ \\
\hline$(\mathrm{cm})$ & \multicolumn{6}{|c|}{ TOC $\left(\mathrm{g} \mathrm{kg}^{-1}\right)$} \\
\hline 0 a 5 & $10.06 \mathrm{Ba}$ & $10.34 \mathrm{Ba}$ & $10.61 \mathrm{Ba}$ & $12.11 \mathrm{Ba}$ & $13.55 \mathrm{Ba}$ & $18.57 \mathrm{Aa}$ \\
\hline 5 a 10 & 8.06Aa & 8.93Aa & $8.73 \mathrm{Aa}$ & $10.57 \mathrm{Aa}$ & $10.19 \mathrm{Ab}$ & $10.22 \mathrm{Ab}$ \\
\hline 10 a 20 & $5.27 \mathrm{Ab}$ & $6.30 \mathrm{Ab}$ & $5.87 \mathrm{Ab}$ & $7.52 \mathrm{Ab}$ & $6.75 \mathrm{Ac}$ & $8.39 \mathrm{Ab}$ \\
\hline \multirow[t]{2}{*}{20 a 40} & $4.48 \mathrm{Ab}$ & $5.18 \mathrm{Ab}$ & $4.07 \mathrm{Ab}$ & $4.88 \mathrm{Ab}$ & 4.72Ac & $4.51 \mathrm{Ac}$ \\
\hline & \multicolumn{6}{|c|}{ C-POM $\left(\mathrm{g} \mathrm{kg}^{-1}\right)$} \\
\hline 0 a 5 & $2.30 \mathrm{Ba}$ & $2.77 \mathrm{Ba}$ & $2.25 \mathrm{Ba}$ & $2.59 \mathrm{Ba}$ & $2.32 \mathrm{Ba}$ & $3.53 \mathrm{Aa}$ \\
\hline 5 a 10 & $1.37 \mathrm{Ab}$ & $1.81 \mathrm{Ab}$ & $1.56 \mathrm{Ab}$ & $2.26 \mathrm{Aa}$ & $1.66 \mathrm{Aa}$ & $1.78 \mathrm{Ab}$ \\
\hline 10 a 20 & $1.01 \mathrm{Ab}$ & $1.15 \mathrm{Ac}$ & $0.85 \mathrm{Ac}$ & $1.28 \mathrm{Ab}$ & $1.05 \mathrm{Ab}$ & $0.83 \mathrm{Ac}$ \\
\hline \multirow[t]{2}{*}{20 a 40} & $0.73 \mathrm{Ab}$ & $0.85 \mathrm{Ac}$ & $0.68 \mathrm{Ac}$ & $1.03 \mathrm{Ab}$ & $0.81 \mathrm{Ab}$ & $0.67 \mathrm{Ac}$ \\
\hline & \multicolumn{6}{|c|}{$\mathrm{C}-\mathrm{COM}\left(\mathrm{g} \mathrm{kg}^{-1}\right)$} \\
\hline 0 a 5 & $7.76 \mathrm{Ca}$ & $7.58 \mathrm{Ca}$ & $8.35 \mathrm{Ca}$ & $9.52 \mathrm{Ba}$ & $11.23 \mathrm{Ba}$ & $15.04 \mathrm{Aa}$ \\
\hline 5 a 10 & $6.69 \mathrm{Aa}$ & 7.11Aa & 7.16Aa & $8.31 \mathrm{Aa}$ & $8.54 \mathrm{Ab}$ & $8.44 \mathrm{Ab}$ \\
\hline 10 a 20 & $4.26 \mathrm{Ab}$ & $5.16 \mathrm{Ab}$ & $5.02 \mathrm{Ab}$ & $6.24 \mathrm{Ab}$ & $5.71 \mathrm{Ac}$ & $7.56 \mathrm{Ab}$ \\
\hline \multirow[t]{2}{*}{20 a 40} & $3.75 \mathrm{Ab}$ & $4.32 \mathrm{Ab}$ & $3.39 \mathrm{Ab}$ & $3.84 \mathrm{Ab}$ & $3.92 \mathrm{Ac}$ & $3.84 \mathrm{Ac}$ \\
\hline & \multicolumn{6}{|c|}{$\mathrm{L}$} \\
\hline 0 a 5 & 0.30 & 0.37 & 0.27 & 0.28 & 0.21 & 0.23 \\
\hline 5 a 10 & 0.20 & 0.25 & 0.22 & 0.28 & 0.19 & 0.21 \\
\hline 10 a 20 & 0.24 & 0.22 & 0.17 & 0.21 & 0.18 & 0.11 \\
\hline \multirow[t]{2}{*}{20 a 40} & 0.19 & 0.20 & 0.20 & 0.27 & 0.21 & 0.18 \\
\hline & \multicolumn{6}{|c|}{$\mathrm{C} / \mathrm{N}$} \\
\hline 0 a 5 & $6.63 \mathrm{Ba}$ & $6.21 \mathrm{Ba}$ & $6.01 \mathrm{Ba}$ & $6.74 \mathrm{Ba}$ & $9.31 \mathrm{Aa}$ & 6.09Aa \\
\hline 5 a 10 & 6.49Aa & 5.98Aa & $5.81 \mathrm{Aa}$ & 6.64Aa & $6.18 \mathrm{Ab}$ & $5.13 \mathrm{Aa}$ \\
\hline 10 a 20 & $5.01 \mathrm{Ab}$ & $5.18 \mathrm{Aa}$ & $5.33 \mathrm{Aa}$ & 5.69Aa & $5.36 \mathrm{Ab}$ & $5.05 \mathrm{Aa}$ \\
\hline 20 a 40 & $4.62 \mathrm{Ab}$ & $4.89 \mathrm{Aa}$ & $4.87 \mathrm{Aa}$ & $4.53 \mathrm{Ab}$ & $5.14 \mathrm{Ab}$ & $3.60 \mathrm{Ab}$ \\
\hline
\end{tabular}

OBS: Olive tree cultivated on bare soil; OSV: olive tree cultivated with spontaneous vegetation; OJB: olive tree cultivation intercropped with jack bean; OML: olive tree cultivation intercropped with Pearl millet; BS: bare soil; NV: Native Vegetation. TOC: Total organic carbon; C-POM: Carbon of particulate organic matter; C-COM: Complexed organic matter carbon; L: Lability; C / N: Relationship between Carbon and Nitrogen. Lower case letters compare the same treatment in depths and upper case letters compare the same depth in different treatments. 
Table 4. Granulometry of erosion sediment.

\begin{tabular}{|c|c|c|}
\hline Treatment & Sand \% & Clay + Silt $\%$ \\
\hline$\overline{\mathrm{OBS}}$ & 48 & 52 \\
\hline OSV & 48 & 52 \\
\hline OJB & 45 & 55 \\
\hline OML & 41 & 59 \\
\hline BS & 49 & 51 \\
\hline
\end{tabular}

OBS: Olive tree cultivated on bare soil; OSV: olive tree cultivated with spontaneous vegetation; OJB: olive tree cultivation intercropped with jack bean; OML: olive tree cultivation intercropped with Pearl millet; BS: bare soil.

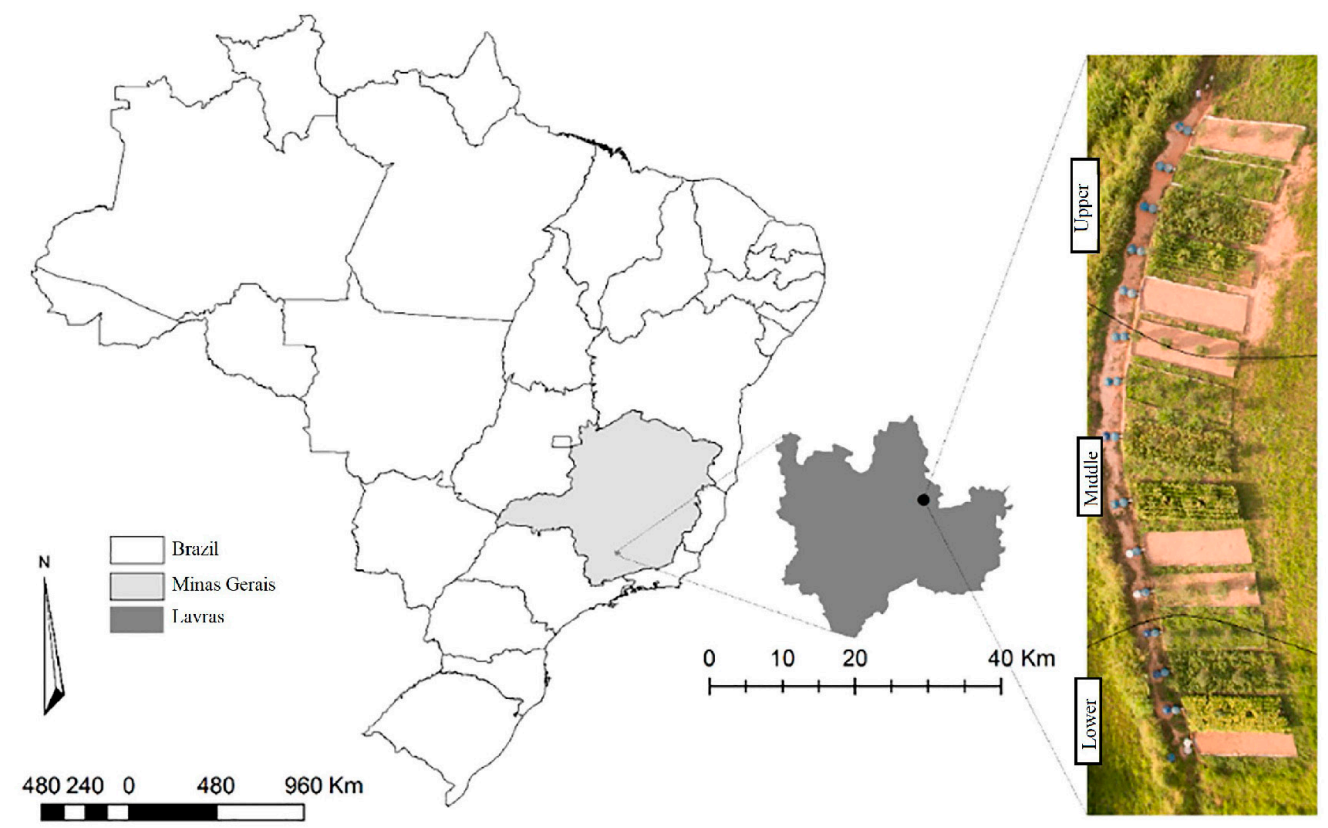

Figure 1. Location of the experimental area with the layout of the standard plots used in the erosion study.

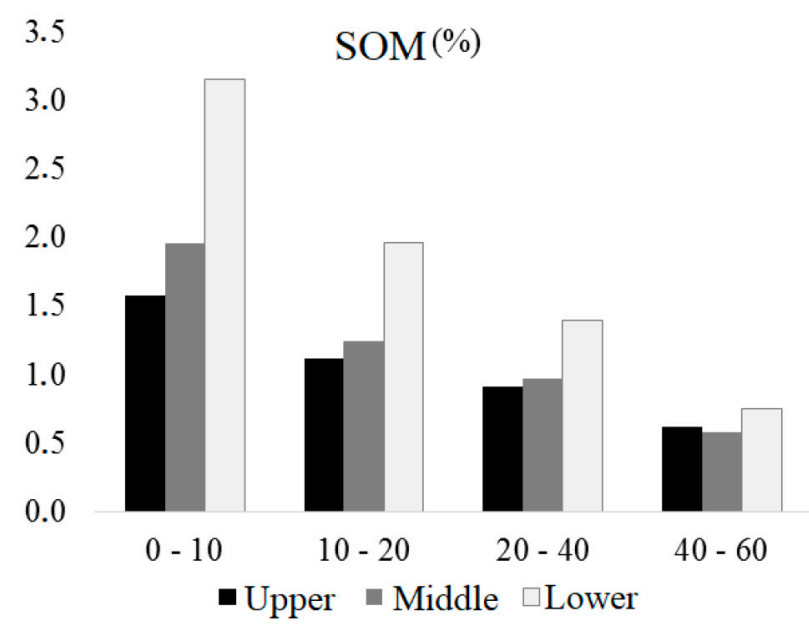

Figure 2. Soil Organic Matter (SOM) in Inceptisol before the experiment in the upper, middle, and lower parts of the slope. 


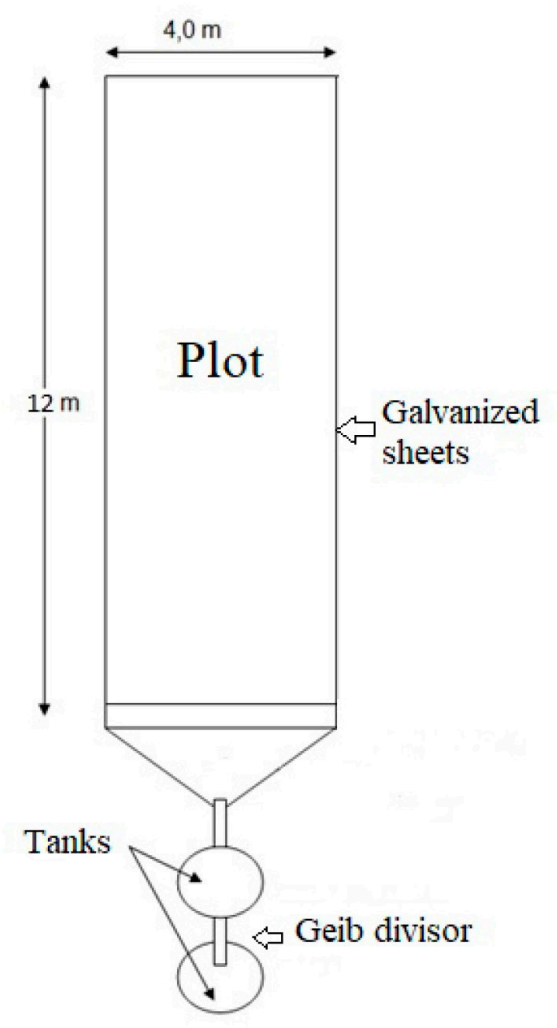

Figure 3. Soil loss plot.

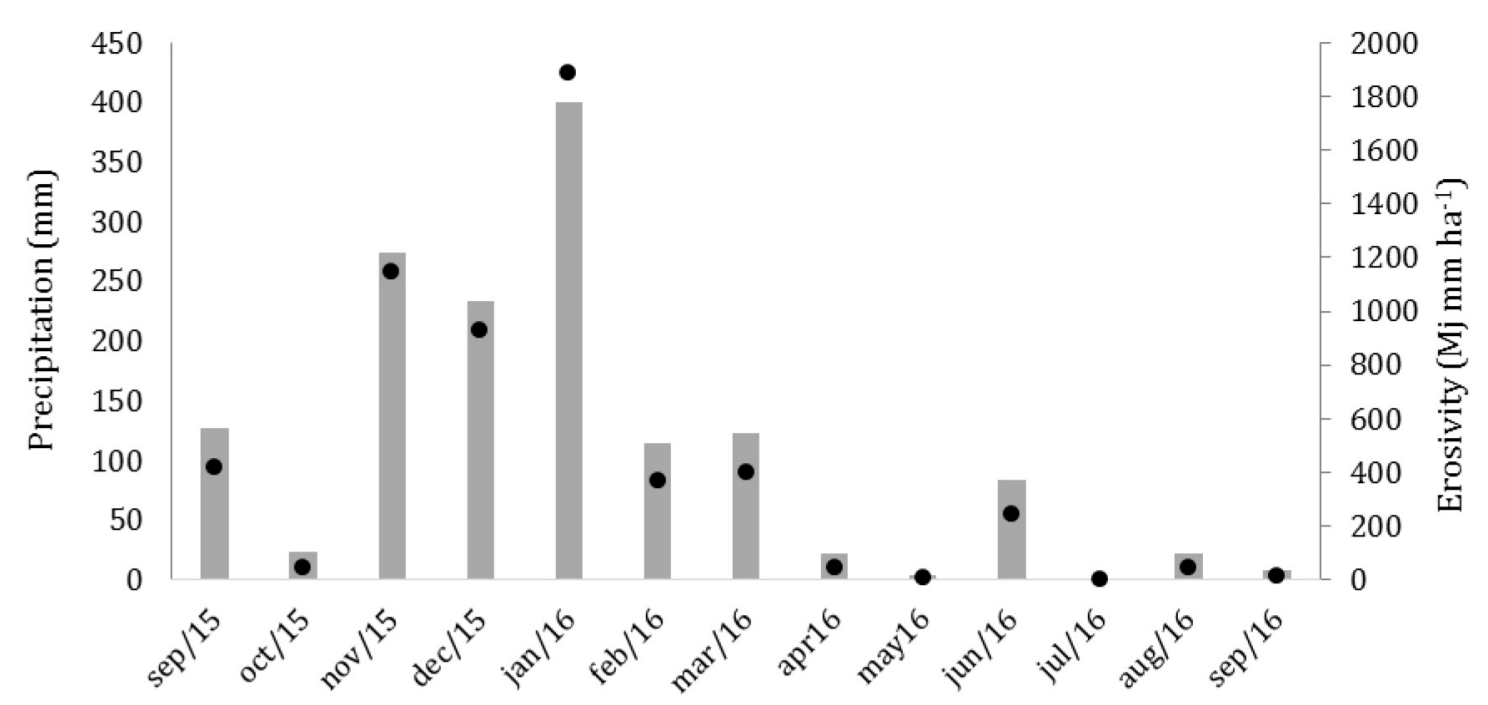

Figure 4. Distribution of precipitation and monthly erosivity in the study period. 


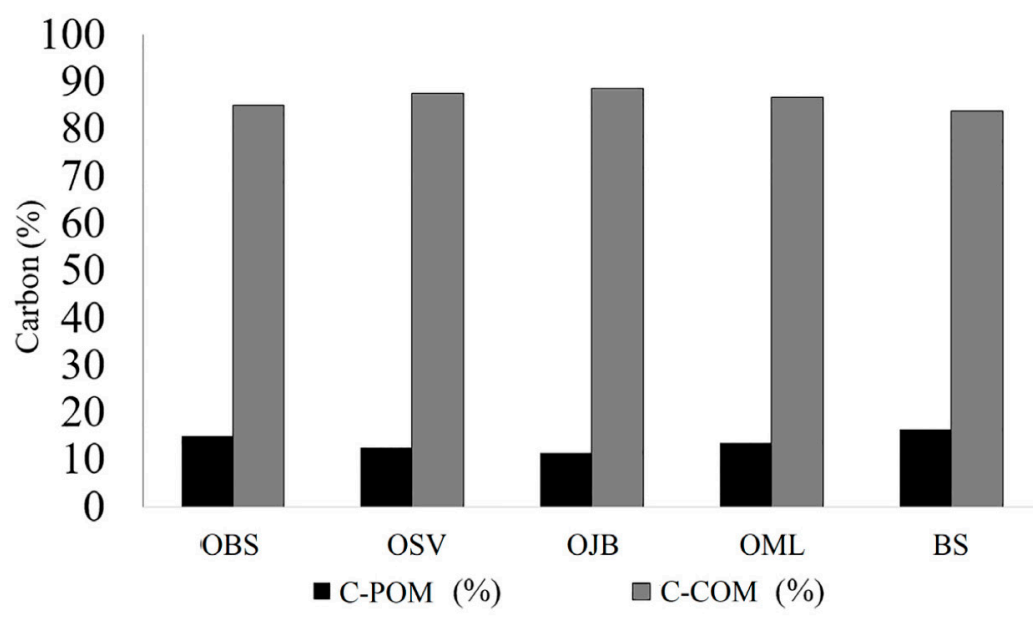

Figure 5. Proportion of C-POM and C-COM in erosion sediment. OBS: Olive tree cultivated on bare soil; OSV: olive tree cultivated with spontaneous vegetation; OJB: olive tree cultivation intercropped with jack bean; OML: olive tree cultivation intercropped with Pearl millet; BS: bare soil.

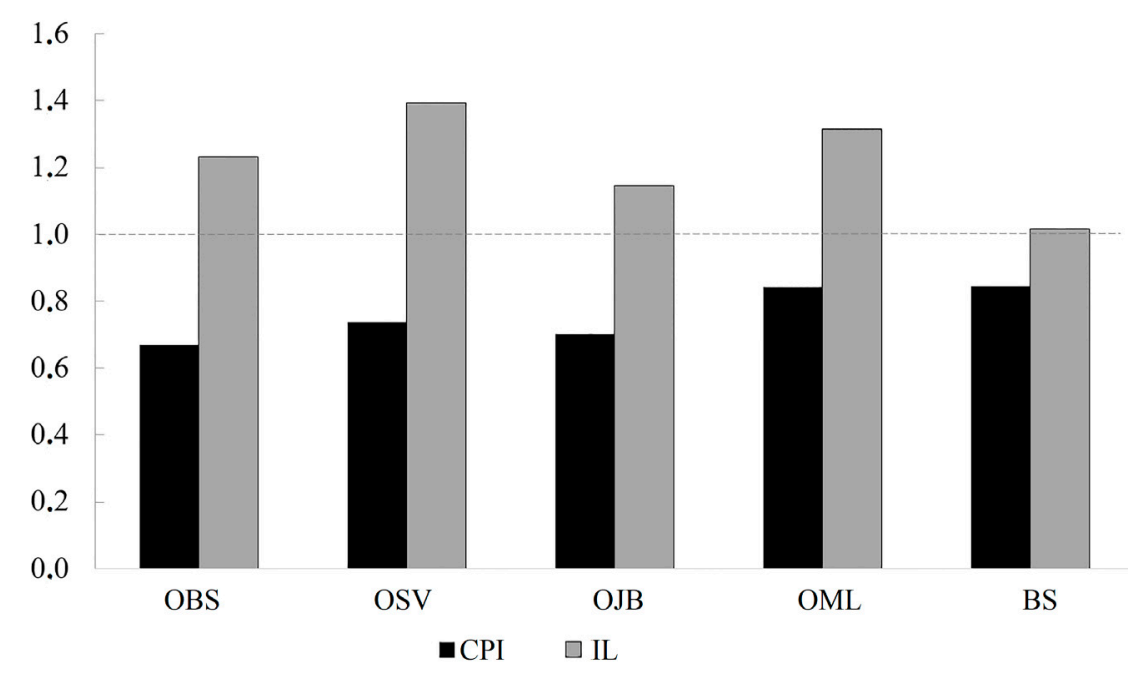

Figure 6. Carbon pool Index (CPI) and Index of Lability (IL) in Inceptisol of Southern Minas Gerais. OBS: Olive tree cultivated on bare soil; OSV: olive tree cultivated with spontaneous vegetation; OJB: olive tree cultivation intercropped with jack bean; OML: olive tree cultivation intercropped with Pearl millet; BS: bare soil. The dashed line represents the reference value (1). 


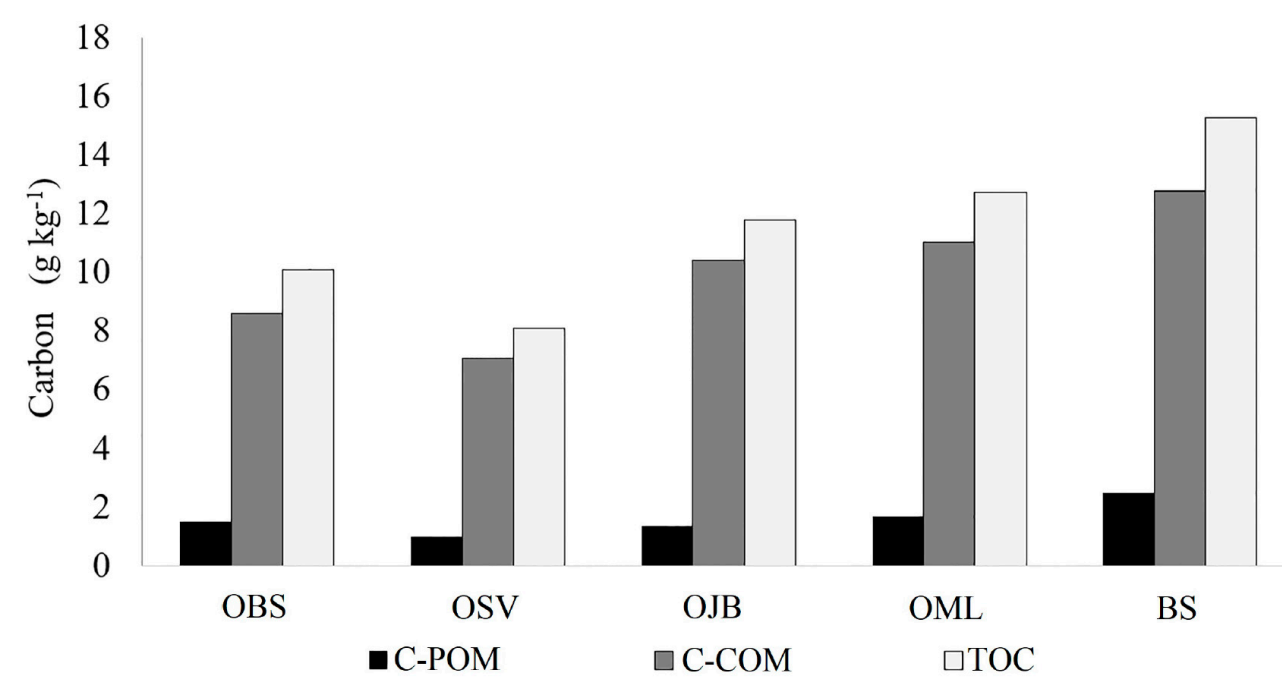

Figure 7. Total carbon and its fractions in the erosion sediment in the vegetation cover management systems in the olive tree. OBS: Olive tree cultivated on bare soil; OSV: olive tree cultivated with spontaneous vegetation; OJB: olive tree cultivation intercropped with jack bean; OML: olive tree cultivation intercropped with Pearl millet; BS: bare soil.

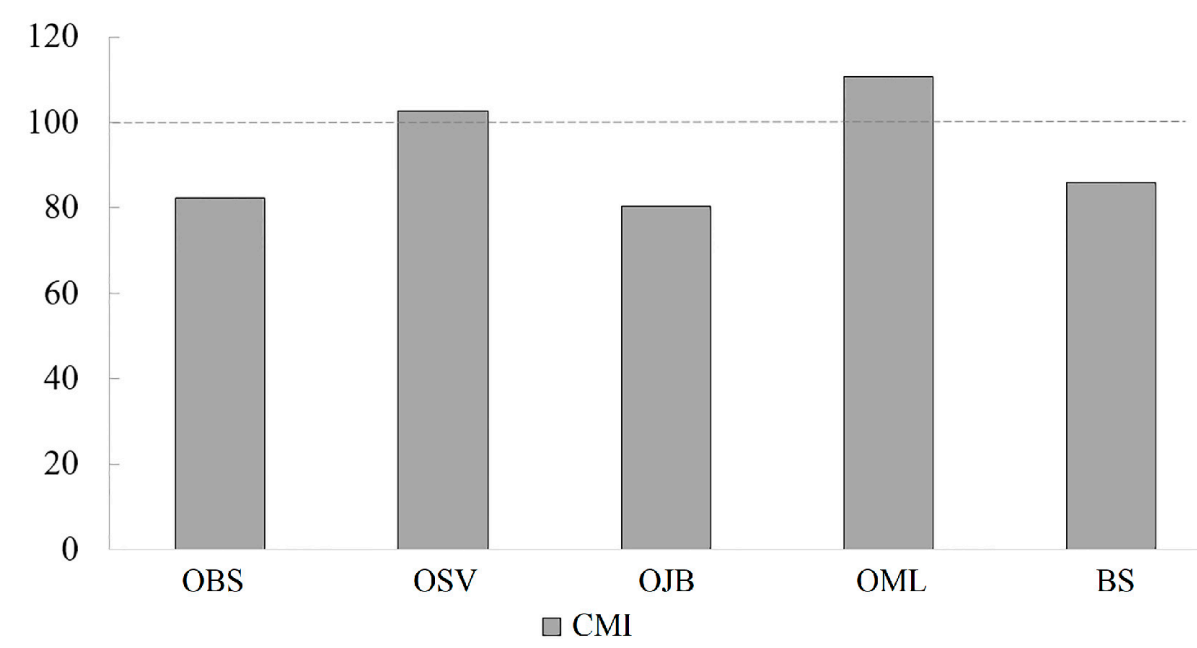

Figure 8. Carbon Management Index (CMI) in Inceptisol of Southern Minas Gerais. The dashed line represents the reference value (100). OBS: Olive tree cultivated on bare soil; OSV: olive tree cultivated with spontaneous vegetation; OJB: olive tree cultivation intercropped with jack bean; OML: olive tree cultivation intercropped with Pearl millet; BS: bare soil.

\section{Conclusions}

The carbon of the particulate organic matter was not efficient in discriminating the soil quality of the studied treatments.

The predominant organic carbon fraction presented in the erosion sediment is the non-labile soil organic carbon fraction.

The carbon management index classified OML and OSV as being the treatments with better soil qualities.

\section{Acknowledgements}

The authors thank CAPES, CNPq (Processes 471522/2012-0, 305010/2013-1, 306511-2017-7, 202938/2018-2 and 150698/2017-8) and FAPEMIG (Processes CAG-PPM-00422-13 and CAG-APQ 0105315) for the financial support. 


\section{References}

ALVARES, C.A.; STAPE, J.L.; SENTELHAS, P.C.; GONÇALVES, J.L.M.; SPAROVEK, G. Koppen's climate classification map for Brazil. Meteorologische Zeitschrift, Stuttgart, v.22, n.6, p.711-728, 2013.

AQUINO, R.F.; SILVA, M.L.N.; FREITAS, D.A.F.; CURI, N.; MELLO, C.R.; AVANZI, J.C. Erosividade das chuvas e tempo de recorrência para Lavras, Minas Gerais. Revista Ceres, Viçosa, MG, v.61, n.1, p.9-16, 2014.

ARTEMYEVA, Z.S.; KOGUT, B.M. The effect of tillage on organic carbon stabilization in microaggregates in different climatic zones of european Russia. Agriculture, Washington, v.6, n.4, p.1-17, 2016.

BARBOSA, J.Z.; FERREIRA, C.F.; SANTOS, N.Z.; MOTTA, A.C.V.; PRIOR, S.; GABARDO, J. Production, carbon and nitrogen in stover fractions of corn ( Zea mays L.) in response to cultivar development. Ciência e Agrotecnologia, Lavras, v.40, n.6, p.665-675, 2016.

BLAIR, G.J.; LEFROY, R.D.B.; LISLE, L. Soil carbon fractions based on their degree of oxidation, and the development of a carbon management index for agricultural systems. Australian Journal of Agricultural Research, Melbourne, v.46, n.7, p.1459-1466, 1995.

CAMBARDELLA, C.A.; ELLIOT, E.T. Particulate soil organic matter changes across a grassland cultivation sequence. Soil Science Society of America Journal, Madison, v.56, p.777-783, 1992.

CONCEIÇÃO, P.C.; BAYER, C.; DIECKOW, J.; CARVALHO DOS SANTOS, D. Fracionamento físico da matéria orgânica e índice de manejo de carbono de um Argissolo submetido a sistemas conservacionistas de manejo. Ciência Rural, Santa Maria, v.44, n.5, p.794800, 2014.

DOETTER, S.; STEVENS, A.; SIX, J.; MERCKX, R.; OOST, K.V.; PINTO, M.C.; CASANOVA-KATNY, A.; MUÑOZ, C.; BOUDIN, M.; VENEGAS, E.Z.; BOECKX, P. Soil carbon storage controlled by interactions between geochemistry and climate. Nature Geoscience, Londres, v.8, n.10, p.780-785, 2015.

FACCIN, F.C.; MARCHETTI, M.E.; SERRA, A.P.; ENSINAS, S.E. Frações granulométricas da matéria orgânica do solo em consórcio de milho safrinha com capim-marandu sob fontes de nitrogênio. Pesquisa Agropecuária Brasileira, Brasília, DF, v.51, n.12, p.2000-2009, 2016.
FERNANDEZ-ROMERO, M.L.; ALCÁNTARA, L.P.; GARCÍA, B.L., CLARK, J.M.; COLLINS, C.D. Soil quality assessment based on carbon stratification index in diferente olive grove management practices in Mediterranean áreas. Catena, Amsterdam, v.137, s/n p.449-458, 2016.

FERREIRA, G.M.R.; MELLONI, R.; SILVA, L.F.O.; MARTINS, F.B.; GONÇALVES, E.D. Fungos micorrizicos arbusculares no desenvolvimento de mudas de oliveira (Olea Europaea L.) cultivadas no Sul de Minas Gerais. Revista Brasileira de Ciência do Solo, Viçosa, MG, v.39, n.2, p.361-366, 2015.

GUIMARÃES, D.V.; GONZAGA, M.I.S.; SILVA, T.O.; SILVA, T.L.; DIAS, N.S.; MATIAS, M.I.S. Soil organic matter pools and carbon fractions in soil under different land uses. Soil \& Tillage Research, Amsterdam, v.126, p.177-182, 2013.

GUIMARÃES, D.V.; GONZAGA, M.I.S.; MELO NETO, J.O. Management of soil organic matter and carbon storage in tropical fruit crops. Revista Brasileira de Engenharia Agricola e Ambiental, Campina Grande, v.18, n.3, p.301306, 2014.

IMETRO - Instituto Nacional de Metrologia, Qualidade e Tecnologia. Programa de análise de produtos: relatório de análise de azeite de oliva extra virgem. Rio de Janeiro, 2015. $21 \mathrm{p}$.

IOOC - International Olive Oil Council. Production techniques in olive growing. Madrid: IOOC, 2003, 346 p.

KUNDE, R.J.; LIMA, C.L.R.; SILVA, S.D.A.; PILLON, C.N. Frações físicas da matéria orgânica em Latossolo cultivado com cana-de-açúcar no Rio Grande do Sul. Pesquisa Agropecuária Brasileira, Brasília, DF, v.51, n.9, p.1520-1528, 2016.

LAL, R. Restoring soil quality to mitigate soil degradation. Sustainability, Basileia, v.7, n.5, p.5875-5895, 2015.

LEITE, L.C.; MENDONÇA, E.S.; NEVES, J.C.L.; MACHADO, P.L.O.A.; GALVÃO, J.C.C. Estoques totais de carbono orgânico e seus compartimentos em argissolo sob floresta e sob milho cultivado com adubação mineral e orgânica. Revista Brasileira de Ciência do Solo, Viçosa, MG, v.27, n.5, p.821-832, 2003. 
LOSS, A.; BASSO, B.S.; OLIVEIRA, L.P.; KOUCHER, R.A.; OLIVEIRA, C.; KURTZ, P.E.; LOVATO, P.; CURMI, G.; BRUNETTO. Carbono orgânico total e agregação do solo em sistema de plantio direto agroecológico e convencional de cebola. Revista Brasileira de Ciência do Solo, Viçosa, MG, v.34, n.4, p.1212-1224, 2015.

LUCIANO, R.V.; BERTOL, I.; BARBOSA, F.T.; KURTZ, C.; FAYAD, J.A. Propriedades físicas e carbono orgânico do solo sob plantio direto comparados à mata natural, num Cambissolo Háplico. Revista de Ciências Agroveterinárias, Lages, v.9, n.1, p.9-19, 2010.

MARTINS FILHO, M.V.; LICCIOTI, T.T.; PEREIRA, G.T.; MARQUES JÚNIOR, J.; SANCHEZ, R.B. Perdas de solo e nutrientes por erosão num Argissolo com resíduos vegetais de cana-de-açúcar. Engenharia Agrícola, Jaboticabal, v.29, n.1, p.8-18, 2009.

MARTINS, L.M.; CRUZ, M.D.C.M.; DE OLIVEIRA, A.F.; FAGUNDES, M.C.P.; DOS SANTOS, J.B. Crescimento inicial de mudas de oliveira em competição com plantas daninhas. Agrarian, Dourados, v.8, n.28, p.124-132, 2015.

OLIVEIRA, A.F.; ANTUNES, L.E.C.; SCHUCH, M.W. Caracterização morfológica de cultivares de oliveira em coleção e considerações sobre o seu cultivo no Brasil. Informe Agropecuário, Belo Horizonte, v.27, n.231, p.55-62, 2006.

OLIVEIRA, D. M. S.; PAUSTIAN, K.; COTRUFO, M. F.; FIALLOS, A.R.; CERQUEIRA, A.G.; CERRI, C.E.P. Assessing labile organic carbon in soils undergoing land use change in Brazil: A comparison of approaches. Ecological Indicators, Amsterdam, v.72, p.411-419, 2016.

SANTOS, H.G.; JACOMINE, P.K.T.; ANJOS, L.H.C.; OLIVEIRA, V.A.; LUMBRERAS, J.F.; COELHO, M.R.; ALMEIDA, J.A.; CUNHA, T.J.F.; OLIVEIRA, J.B. Sistema Brasileiro de Classificação de Solos. 3.ed. Brasília: EMBRAPA, 2013. 353p.

SANTOS, F.A.S.; PIERANGELI, M.A.P.; SILVA, F.L.; SERAFIM, M.E.; DE SOUSA, J.B.; DE OLIVEIRA, E.B. Dinâmica do carbono orgânico de solos sob pastagens em campos de murundus. Scientia Agraria, Curitiba, v.18, n.2, p.43-53, 2017.

SASTRE, B.; BARBERO-SIERRA, C.; BIENES, R.; MARQUES, M.J.; GARCÍA-DÍAZ, A. Soil loss in an olive grove in Central Spain under cover crops and tillage treatments, and farmer perceptions. Journal of Soils and Sediments, North Andover, v.17, n.3, p.873-888. 2017.
SHENG, H.; ZHOU, P.; ZHANG, Y.; KUZYAKOV, Y.; ZHOU, Q.; GE, T.; WANG, C. Loss of labile organic carbon from subsoil due to land-use changes in subtropical China. Soil Biology and Biochemistry, Amsterdam, v.88, p.148-157, 2015.

SILVA, F.C. Manual de análises químicas de solos, plantas e fertilizantes. 2.ed. Brasília: EMBRAPA, 2009. $627 \mathrm{p}$.

SILVA, G.N.; BONETTI, J.A.; SOUZA, E.D.; PAULINO, H.B.; CARNEIRO, M.A.C. Management systems and soil use on fractions and stocks of organic carbon and nitrogen total in cerrado Latosol. Bioscience Journal, Uberlândia, v. 32, n.6, p. 1482-1492, 2016.

SOUZA, E.D.; COSTA, S.E.V.G.A.; ANGHINONI, I.; CARNEIRO, M.A.C.; MARTINS, A.P.; BAYER, C. Soil quality indicators in a Rhodic Paleudult under long term tillage systems. Soil and Tillage Research, Amsterdam, v.139, s/n, p.28-36, 2014.

SOUZA, K.R.; MELLONI, R.; FERREIRA, G.M.R.; SOUZA, S.M.P.; REZENDE, J.T. Proposta da Metodologia RAQS para avaliação visual da qualidade do solo. Revista Brasileira de Geografia Física, Recife, v.9, n.6, p.18151824, 2016.

VIEIRA NETO, J.; OLIVEIRA, A.F. de; OLIVEIRA, N.C. de; DUARTE, H. da S.S.; GONÇALVES, E.D. Aspectos técnicos da cultura da oliveira. Belo Horizonte: Epamig, 2008. 56p. (Boletim Técnico, 88).

WREGE, M.S.; COUTINHO, E.F.; PANTANO, A.P.; JORGE, R.O. Distribuição potencial de oliveiras no brasil e no mundo. Revista Brasileira Fruticultura, Jaboticabal, v.37, n.3, p.656-666, 2015.

YEOMANS, J. C.; BREMNER, J. M. A rapid and precise method for routine determination of organic carbon in soil. Communications in Soil Science and Plant Analysis, New York, v.19, n.13, p.1467-1476, 1988.

ZHAO, F.; YANG, G.; HAN, X.; FENG, Y.; REN, G. Stratification of carbon fractions and carbon management index in deep soil affected by the Grain-to-Green program in China. PloS one, San Francisco, v.9, n.6, p. e99657, 2014.

ZHAO, X.; WU, P.; GAO, X.; PERSAUD, N. Soil quality indicators in relation to land use and topography in a small catchment on the Loess Plateau of China. Land Degradation \& Development, Medford, v.26, n.1, p.5461, 2015. 